Iwona Pugacewicz

Warszawa

\title{
W obronie francuskiego dziedzictwa kulturowego. Działalność Henri Grégoire na rzecz ochrony książki i sztuki w okresie Wielkiej Rewolucji Francuskiej*
}

Powszechnie wiadomo, że temat szeroko pojmowanej przemocy okresu rewolucji francuskiej 1789-1799, zarówno jej destrukcyjnego, jak i ,życiodajnego" oblicza, począwszy od obalenia Bastylii, poprzez różne odcienie terroru wspomaganego ostrzem gilotyny, skończywszy wreszcie na aktach wandalizmu i walki z wandalizmem, doczekał się wielu cennych opracowań, a pomimo tego nadal wydaje się być niewyczerpany. Interesująca nas tutaj troska o książkę, ochrona pierwszych archiwów i bibliotek również mają swoją własną pokaźną literaturę. Przyjrzyjmy się historii tego zjawiska, jego początkom, a przede wszystkim bohaterom tamtych czasów wojujących piórem na rzecz obrony francuskiego dziedzictwa piśmienniczego, jednostkom stawiającym czoła wandalizmowi w epoce, gdzie taka postawa - utożsamiana z obroną starego ładu - mogła kosztować życie.

Niewątpliwie do panteonu pierwszych denuncjatorów wandalizmu, do grona pionierów głośno potępiających zniszczenia i stających na straży całości bibliotek należy zaliczyć niejakiego Henri Grégoire’a, niegrzeszącego skromnościąjezuitę z Nancy, który m.in. sam sobie przypisywał wprowadzenie pojęcia „wandalizm” do powszechnego obiegu, w ramach rewolucyjnej

*Artykuł powstał w ramach projektu sfinansowanego ze środków Narodowego Centrum Nauki, przyznawanych na podstawie decyzji nr DEC-2011/03/B/HS2/05446.

${ }^{1}$ Interesujacca bibliografia rewolucyjnej przemocy, z podziałem na poszczególne jej rodzaje, została zawarta w książce Jean-Clément Martin, Violence et Révolution. Essai sur la naissance d'un mythe national, Paris 2006, s. 315-332; zob. też Daniel Hermant, Destructions et vandalisme pendant la Révolution française, „Annales. Économies, Sociétés, Civilisations", 33(4):1978, s. 703-719. 
retoryki². Ów „kapłan rewolucji” ${ }^{3}$ - jak nazwała go autorka jego biografii Rita Hermont-Belot - urodzony w 1750 r. w miejscowości Vého, niedaleko Lunéville, od najmłodszych lat przejawiał wyjątkowe zamiłowanie do nauki, a lekturze przypisywał wszelkie znamiona wolności. Zanim został proboszczem w parafii Embersnil, gdzie jednym z pierwszych jego działań było otwarcie - na potrzeby wszystkich wiernych - poskładanej ze swoich prywatnych zbiorów książnicy, nauczał w kolegium Pontà-Mousson. Tam właśnie uświadomił sobie potrzebę powszechnego dostępu do książki i bibliotek. Z przedrewolucyjnej aktywności ojca Grégoire'a warto wspomnieć o napisanej i wydanej przez niego książce pt. Szkic na temat odrodzenia fizycznego i moralnego Żydów ${ }^{4}$, której sam tytuł najlepiej świadczy o niezwykłej, jak na tamte czasy, odwadze duchownego, o wynikającym z jego poglądów przekonaniu o potrzebie tolerancji i sprawiedliwości społecznej.

Nie dziwi więc fakt natychmiastowego przystapienia jezuity do francuskiej rewolucji. Już w 1789 r. zasiadał on w Stanach Generalnych po stronie najniższego kleru i ludu, ażeby po kilku miesiącach stać się jednym z bardziej wpływowych przedstawicieli stanu trzeciego. Jako pierwszy poprzysiagł w słynnej sali gry w piłkę, iż deputowani stanu trzeciego nie rozejdą się aż do momentu uchwalenia konstytucji (20 czerwca 1789 r.). Jako pierwszy też, w niecały rok później, złożył przysięgę posłuszeństwa wobec konstytucji cywilnej duchowieństwa (Constitution civile du clergé), zgodnie z którą biskupi i proboszczowie mieli być obierani w taki sam sposób, jak wszyscy inni urzędnicy, a więc podlegać państwowej władzy świeckiej. Wśród najbliższych przyjaciół ojca Grégoire'a widzimy Robespierre'a i Mirabeau. Po tzw. wydarzeniu w Varennes - próbie ucieczki Ludwika XVI z Francji (20 czerwca 1790 r.) - cała trójka potępia króla, ale wówczas jeszcze ani ojciec Grégoire, ani pozostali nie domagali się śmierci monarchy, a jedynie sprawiedliwego procesu lub odwołania. Czasy terroru dopiero się zbliżały. Zdanie, które na trwałe wpisało się w losy rewolucji: „Historia królów to męczeństwo narodów" (L’histoire des rois est la martyrologie des nations $)^{5}$ właśnie wówczas wypowiedział ojciec Grégoire, który jedno-

${ }^{2}$ Więcej na temat najwcześniejszych raportów dotyczących aktów niszczenia m.in. książek i bibliotek zob. w pracy: Bernard Deloche, Jean-Michel Leniaud, La culture des sans-culottes. Le premier dossier du patrimoine 1789-1798, Paris 1989.

${ }^{3}$ Rita Hermon-Belot, L'abbé Grégoire, la politique et la vérité, Paris 2000, passim.

${ }^{4}$ Zob. Henri Grégoire, Essai sur la régéneration physique, morale et politique des Juifs, ouvrage couronné par la Société royale des sciences et des arts de Metz, le 23 août 1788 par M. Grégoire, curé du diocèse, actuellement dans la même société, Paris 1788.

${ }_{5}^{5}$ Graham K. Barnett, Histoire des bibliothèques publiques en France de la Révolution à 1939, Paris 1987, s. 38-39. 
cześnie domagał się, wbrew rewolucyjnej logice, całkowitego zniesienia kary śmierci ${ }^{6}$. Jego poglądy, wykształcenie, wiedza, a przede wszystkim odwaga innego myślenia predestynowały go do zajmowania najwyższych stanowisk, nie tyle politycznych, ile tych urzędowych, związanych z administracją i zarządzaniem przejętymi dobrami kultury. Jako członek - już od 1791 r. - Komitetu Instrukcji Publicznej (Comité d'instruction publique), poza swoją główną działalnością biblioteczną wspierał utworzenie Szkoły Sztuk i Rzemiosł (Conservatoire des arts et métiers - 1794 r.), a także Instytutu Francuskiego (l'Institut de France - 1795 r.), z którym szczególnie blisko współpracował - ten krzewiciel nauki i obrońca kultury narodowej sporządzał m.in. dla ówczesnych władz raporty o stanie francuskiego dziedzictwa piśmienniczego.

Niestrudzony orędownik powszechnej edukacji poza głównym nurtem swoich prac, jakim była ochrona bibliotek i ich księgozbiorów, zajął się także tworzeniem podręczników do powszechnego nauczania elementarnego, walczył z różnymi dialektami i naleciałościami na rzecz czystości i jednorodności języka francuskiego, zakładał ogrody botaniczne, gospodarstwa doświadczalne z myślą o rozwoju nauki i edukacji, bronił praw nie tylko Żydów, lecz także czarnoskórej mniejszości, a z drugiej strony silnie podkreślał potrzebę szerzenia jednej katolickiej wiary ${ }^{7}$. Zapowiadający mające nadejść czasy, wyklęty przez klerykalny tradycjonalizm, wyniesiony i doceniany przez rewolucję, jako jeden z nielicznych odważył się na krytykę jej słabych stron - tych dotykających sfery kultury, ale też wszelkiego typu matactw, nadużyć finansowych i spisków, niezależnie od politycznej opcji.

Powróćmy jednak do głównego nurtu działalności ojca Grégoire'a-ochrony piśmiennictwa narodowego. Najważniejszym celem prac podjętych przez jezuitę w Komitecie Instrukcji Publicznej było nieustanne zapobieganie jakimkolwiek aktom niszczenia i dewastacji. Owe zabiegi wynikały z potrzeby chwili, z dostrzeżenia problemu, nad którym inni przechodzili do porządku dziennego. Ażeby uświadomić Konwencji skalę zjawiska francuskiego wandalizmu i jego potencjalne konsekwencje, zakonnik sporządził na ten temat trzy raporty, które po dziś dzień stanowią jedno z najważniejszych źródeł dotyczacych przemocy i destrukcji tamtych czasów.

Niewatpliwie rewolucja nie potrafiła ani zaakceptować, ani zaadaptować dziedzictwa ancien régime'u, ale w tle owych niewyobrażalnych wręcz zniszczeń dóbr kultury zaczęła rozwijać się, zapożyczona z epoki

${ }^{6}$ Zob. R. Hermon-Belot, dz. cyt., s. 177-182.

${ }^{7}$ W latach 1795-1803 z inicjatywy ojca Grégoire'a były wydawane „Annales de la religion", promujące działalność konstytucyjnego Kościoła. 
oświecenia, myśl o potrzebie obrony historii narodowej i jej śladów. Trzy raporty H. Grégoire'a odgrywały w końcu XVIII w. podobną rolę jak referat Nikity Chruszczowa wygłoszony na XX zjeździe KPZR, ujawniający zbrodnie Stalina przeciw narodowi ${ }^{8}$, aczkolwiek w pierwszym przypadku chodziło o przestępstwa popełniane na dziedzictwie narodowym, ale również przeciw narodowi. W obu momentach dziejowych zresztą najbardziej winna była sama ideologia, polityka tamtych czasów, która przyzwalała, a raczej generowała takie działania.

Pierwszy z trzech dokumentów, z 31 fructidora II r. według obowiązującego wówczas kalendarza rewolucji (31 sierpnia 1794 r.), zaczyna się od skargi, że nie ma dnia w codziennej pracy ojca Grégoire'a, w którym nie doniesiono by mu o jakimś nowym akcie symbolicznej przemocy wobec książki i biblioteki. W ciagu ostatnich pięciu lat, pomimo różnych gróźb i zakazów ze strony władz państwowych, jezuita obserwuje więc wyraźny wzrost wszelkiego rodzaju dewastacji i apeluje o podjęcie środków mających na celu zapobieżenie niszczycielskiej działalności. Donosi, że wbrew poleceniu opieczętowania pomieszczeń, w których składowane są przejęte przez państwo kolekcje prywatne i duchowne, wydanemu 23 października 1790 roku, nie dość, że większość depozytów nie przysłała do Komitetu Instrukcji aktualnych inwentarzy, to na dodatek niezgodnie z prawem organizowała i nadal organizuje publiczne wyprzedaże czy nawet pokątnie spienięża część swoich zbiorów9 ${ }^{9}$ Nawet po kolejnym dekrecie zakazującym tego typu akcji z 10 października 1792 r. ów haniebny proceder nie ustał i tak np. w miastach Lure, Cusset czy Saint-Maixent dopuszczano się nadal przeprowadzania tego typu went, a to, czego nie sprzedano, pozostawiano często pod gołym niebem na deszczu, zwlekając ze sprzątnięciem. Problem tzw. dépôts littéraires, czyli czasowych depozytów książek znacjonalizowanych przez rewolucję (składy te zorganizowano na mocy dekretów z 23 i 28 października 1789 r. w celu zwożenia i przechowywania konfiskowanych zbiorów), dotyczył niewłaściwie wybranych magazynów, a przede wszystkich - panujących w większości z nich fatalnych warunków do przechowywania zarekwirowanych dóbr. Już sam transport był przyczyną strat. Zbiory zwożono z całej okolicy, tj. z dystryktu, do z góry wyznaczonego miasta, przy czym książki chaotycznie ładowano na chłopskie fury, nieprzystosowane w żaden sposób do przeprowadzki kolekcji. Całe biblioteki kongregacyjne czy inne po przewiezieniu na wskazane miejsce były zrzucane na jeden wielki stos, najczęściej bez jakichkolwiek

${ }^{8}$ Zob. Jacques Dumaine, Bibliothèques et Révolution Française, [w:] Le Livre Noir de la Révolution Française, red. Renaud Escande, Paris 2008, s. 279.

${ }^{9}$ Zob. G.K. Barnett, dz. cyt., s. 40. 
spisów czy chociażby prowizorycznego oddzielenia od pozostałych, wcześniej i z innych miejsc przywiezionych zbiorów. Jako dobry przykład takiej powszechnej niefrasobliwości i niewłaściwego przechowywania podał H. Grégoire dépôts litteraires w miejscowości Arnay, gdzie powkładano książki w puste kadzie od wina ${ }^{10}$. Ponadto opisywał on liczne akty zamierzonego wandalizmu, polegające na tym, że część władz lokalnych z premedytacją niszczyła dostarczane kolekcje, ażeby nie zadawać sobie trudu ich katalogowania (przykłady: w Narbonne część książek po prostu spalono, a część odesłano do pobliskiego Arsenału na potrzeby tamtejszej ludwisarni; w Douai władze miejskie wydały rozkaz spalenia wszystkich książek traktujących o religii; w Fontaine-lès-Dijon oddano bibliotekę Feuillants do przemiału, celowego zniszczenia, aby uniknać dodatkowej pracy $)^{11}$. Niekiedy administracja usprawiedliwiała palące się stosy zbyt dużą liczbą bezużytecznych pozycji (np. literatura kościelna), niestosownymi, antyrepublikańskimi, szokującymi opinię publiczną ilustracjami lub inkrustacjami arystokratycznymi. Jezuita dostrzegał też zaraźliwą wręcz powszechną dewastację, jak np. wyrywanie skórzanych opraw lub kart opatrzonych herbem czy innym niezgodnym z duchem epoki znakiem, o czym wyżej była mowa. Wróćmy raz jeszcze do warunków składowania: zdecydowana większość depozytów, jak wynikało z raportów zakonnika, ucierpiała z powodu wilgoci i niskiej temperatury zima, gdyż pomieszczeń magazynowych nie ogrzewano, a książki leżały bezpośrednio na ziemi. Nie lepiej wyglądały zbiory umieszczone na strychach, jak w przypadku depozytu Bernay, o którym zapomniano aż do 1863 roku. Jakież było zdziwienie władz miejskich, gdy odkryły one cztery tysięce książek zamkniętych na poddaszu merostwa na prawie trzy czwarte wieku ${ }^{12}$.

W pierwszym raporcie $H$. Grégoire próbował uświadomić ówczesnym władzom nie tylko skalę zjawiska, jakim było znacjonalizowanie księgozbiorów, lecz także zwracał uwagę na setki tysięcy pozycji o wyjątkowej wartości z punktu widzenia francuskiej kultury. Według współczesnych wyliczeń w samym Paryżu w 1794 r. składowano w depozytach 1,6 mln różnego typu przejętych woluminów, na prowincji zaś w magazynach i książnicach republiki pozostawało co najmniej 6 mln jednostek ${ }^{13}$. Nietrudno, nawet przy tak szacunkowych danych, wyobrazić sobie skalę przestępstw dotykających nieuporządkowane francuskie piśmiennictwo

${ }^{10}$ Zob. Lucien X. Polastron, Livres en feu. Histoire de la destruction sans fin des bibliothèques, Paris 2004, s. 218.

${ }^{11}$ Zob. tamże, s. 191.

12 Zob. G.K. Barnett, dz. cyt., s. 77.

${ }^{13}$ Zob. Denis Pallier, Les bibliothèques, Paris 2006, s. 37. 
narodowe. Niewłaściwie zabezpieczone, cały czas przenoszone z miejsca na miejsce, przy okazji kontrolowane przez niewyobrażalną liczbę cenzorów, zarówno tych rządowych, zmieniających się w zależności od koniunktury politycznej, jak i samozwańczych, książki służyły do wymyślanych różnorodnych celów pozaczytelniczych, ale też jako zwykły materiał piśmienniczy, np. jako papier do katalogowania depozytów ${ }^{14}$.

Reakcję na pierwszy raport stanowił nowy dekret Konwencji z 14 fructidora roku II (31 sierpnia 1794 r.), mówiący o tym, że biblioteki winny być chronione przez wszystkich uczciwych obywateli, a nie tylko powołanych do tego celu strażników. I tak do rangi obowiązku społecznego urosło denuncjowanie pkażdego, kto dopuści się próby gwałtu na jakiejkolwiek literaturze.

Cztery miesiące później ukazało się drugie sprawozdanie ojca Grégoire'a, sporządzone dla Komitetu Instrukcji Publicznej, w którym donosił o kolejnych nadużyciach, a przede wszystkim wskazywał wspólnoty niedbające o swoje depozyty i nieprzestrzegające przepisów. W Ussel, Saumur i Lons-le-Saulnier sprzedawano książki poniżej ich rzeczywistej wartości. W Douai spalono wszystkie pozycje traktujące o religii, które stanowiły przeszło połowę zbiorów tamtejszej biblioteki, a w Etain wykradziono najcenniejsze zabytki kapucynów, jak i te składowane w opactwie Chantillon. Nieustannie też płynęły doniesienia z ulicy SaintMarc o regularnym okradaniu jednego z większych depozytów Paryża - Cordeliers, który - jak się później okazało - nie miał też szczęścia do nadzorców. Właśnie u jednego z konserwatorów odpowiedzialnych za bezpieczeństwo składu Cordeliers, niejakiego obywatela Dambreville'a, znaleziono (w jego prywatnym mieszkaniu) dziewięć i pół tysiąca przywłaszczonych sobie książek ${ }^{15}$. W Arles, zdaniem autora raportu, celowo zezwolono na zniszczenie przez szczury i myszy zarówno księgozbioru, jak i innych niewykradzionych obiektów, jak obrazy, które gryzonie pocięły, czy poodbijane z grup posagowych rzeźby. Przykłady można mnożyć, ale najważniejsze wydają się być nowe motywy takich aktów wandalizmu. Według H. Grégoire'a teraz nie tyle wynikały one ze szczerej, acz naiwnej, chęci rozprawienia się z bogactwem i niesprawiedliwością zbiegłej przed terrorem arystokracji, zarówno świeckiej, jak i duchownej, co towarzyszyły przemyślanym działaniom kontrrewolucji. Czynów tych

${ }^{14}$ Kiedy brakowało potępionych przez rewolucję kart do gry, powszechnie używanych jako katalogowe, z co bardziej solidnych książek wyrywano strony tytułowe, ażeby na pustym odwrocie dokonać właściwego zapisu bibliograficznego kolejnej pozycji (zob. G.K. Barnett, dz. cyt., s. 58).

${ }^{15}$ Zob. tamże, s. 59. 
nie popełniał więc prosty lud, nie miały one na celu zaprowadzenia równości społecznej. Tym razem wandalizmu dopuszczali się ci, przeciwko którym rewolucja wymierzyła swoje ostrze, aby ośmieszyć ją w oczach uczciwych i niczego nieświadomych Francuzów. Ojciec Grégoire wzywał wobec tego wszystkich obywateli do wzmożonej czujności i obrony wspólnej własności narodowej, a także przestrzegał przed wciaganiem zwyczajnych ludzi w tego typu działania wymierzone w młodą I Republikę. Jezuita powoływał się na wcześniejsze doniesienia z Marsylii, w których opisany został plan spalenia przez kontrrewolucjonistów wszystkich bibliotek $^{16}$, i próbował zmusić władze do wzmożonej czujności w kwestii ich ochrony i opieki nad depozytami.

W oparciu o ów drugi raport Konwencja wydała kolejne zarządzenie, z 8 brumaire'a roku III (29 listopada 1794 r.), które nakładało na administrację poszczególnych dystryktów odpowiedzialność za wszelkie straty publicznego mienia, a tym samym mobilizowało ją do jeszcze większej czujności, a także nakazywało sporządzenie listy dokonanych do tej pory kradzieży - w celu ich analizy i podjęcia stosownych dochodzeń.

Wraz ze śmiercią Ludwika XVI (21 stycznia 1793 r.) Francja znalazła się w konflikcie z niemal całą Europa, za wyjątkiem Szwajcarii i Turcji. Niepowodzeniom i trudom wojennym towarzyszyła wspomniana nasilająca się kontrrewolucja, rozgrywki wewnętrzne, podziały i wreszcie rządy Wielkiego Terroru. Tak więc w latach 1793-1794 w propagandowych hasłach walki z wandalizmem pojawiają się nowe ważne argumenty - związane z jawną bądź ukrytą działalnością przede wszystkim wroga wewnętrznego, a tuż za nim, na drugim miejscu - tego zewnętrznego. W ramach różnorodnych działań szeroko rozumianej kontrrewolucji każdy mógł być podejrzany o działalność na szkodę państwa, a za to groziła gilotyna. Wandalizm został sprytnie ukierunkowany przez wrogów ówczesnej młodej republiki na niszczenie dóbr narodowych. Sprytnie, gdyż jego akty - często dokonywane przez niczego nieświadomych, umiejętnie podburzanych gorliwych zwolenników nowej formy ustrojowej - miały ośmieszyć rząd, ukazać jego płytkość intelektualną oraz niezrozumienie dla potrzeby posiadania i ochrony wspólnego dziedzictwa narodowego. Ów nowy rząd - miała głosić kontrrewolucyjna zagraniczna propaganda - buduje swoja siłę na destrukcji i rozprawieniu się ze starym ustrojem i jego warstwami uprzywilejowanymi na zasadzie unicestwienia kultury. Czy tak klasyfikowane zniszczenia i przejawy wandalizmu były faktem rzeczywistym, czy też wymyślonym ze względu na potrzebę chwili przez samych zaintereso-

${ }^{16}$ Zob. R. Hermon-Belot, dz. cyt., s. 304. 
wanych, w celu opanowania chaosu, powstrzymania wszelkimi metodami przed bezmyślną dewastacją, czy też stanowiły próbę solidaryzowania się mas wobec wymyślonych działań wewnętrznego i zewnętrznego wroga, aby ratowa majątek narodowy przed ruiną - zdania są podzielone ${ }^{17}$.

W niespełna dwa miesiące od opublikowania drugiego raportu wychodzi kolejny. Większość aktów wandalizmu wobec książek, książnic i depozytów znamy z wcześniejszych doniesień, chociaż tym razem autor wskazuje inne miejsca i nowe okoliczności. Część ostrzeżeń dotyczy znowu fatalnych warunków przechowywania, bezmyślnego zamykania niby z braku czytelników - pierwszych, nielicznych jeszcze publicznych bibliotek bądź też przeznaczania ich pomieszczeń np. na stodoły i zapychania ich słoma, przydatniejszą wówczas niż nawet najlepsza lektura, jak to było w przypadku Dijon. Co więcej, w najbliższym sąsiedztwie tego typu instytucji w Dijon hodowano świnie i, jak to barwnie opisał nasz bohater, „fetor był tak zaraźliwy, że przeniknął okładki książek"18 do tego stopnia, że nie nadawały się one do użytku.

O ile ów przykry zapach można było zignorować, gdyż nie stanowił on zapewne głównego powodu zniszczenia ówczesnych księgozbiorów, tak pożary, i to tych największych i najcenniejszych kolekcji, łącznie z Saint-Germain-des-Prés z 27 sierpnia 1794 roku, czy w kilka dni później (31 sierpnia 1794 r.) - biblioteki Saint Sulpice, zdarzały się nader często i naprawdę stanowiły plagę tamtych lat. Biblioteka dawnego opactwa Saint-Germain-des-Près, licząca w przededniu rewolucji prawie 50 tys. drukowanych woluminów i ponad 7 tys. rękopisów, była jedną $z$ najcenniejszych i najwcześniej oddanych do publicznego użytku. Wraz z nastaniem nowych czasów i rozpoczęciem przez Francję wojen z całą Europa rozszerzono zakres jej funkcjonowania - w centrum kościoła urządzono laboratorium produkujące niezbędną do wyrobu amunicji saletrę, w wirydarzu - ludwisarnię, a w nawach bocznych składowano węgiel. W wyniku sierpniowej przypadkowej eksplozji większość zbiorów spłonęła lub została zniszczona w trakcie gaszenia pożaru, a to, co w pośpiechu zdołano wyrzucić poza obręb budynku, padło m.in. ofiara grabieży ${ }^{19}$. Podobny

\footnotetext{
${ }^{17}$ Serge Bianchi uznaje sporą część tego typu oskarżeń jedynie za próbę rozprawienia się z wrogami rewolucji, na czele z nielubianym wówczas przez Henri Grégoire'a Maksymilianem Robespierre'em, a nie za rzeczywisty spisek przeciwko niej; stąd potrzeba nowego oszacowania wymiarów rewolucyjnego wandalizmu - zob. Serge Bianchi, Les fausses évidences du "vandalisme révolutionnaires», [w:] La Révolution française. Une histoire toujours vivante, red. Michel Biard, [Paris] 2010, s. 403-404.

18 „Il en est résulté une telle infection, qu'elle a altéré les couvertures des livres”cyt. za : G.K. Barnett, dz. cyt., s. 41.
}

${ }^{19}$ Zob. L.X. Polastron, dz. cyt., s. 223. 
los spotkał druga ze wspomnianych kolekcji - wprawdzie nie tak bogaty, ale równie nobliwy księgozbiór opactwa Saint-Sulpice. „Złe sąsiedztwa” w postaci składów broni, wytwórni prochu, ludwisarni miały m.in. tak wielkie biblioteki, jak Narodowa, Arsenału czy paryskie depozyty Montmorency i Saint-Louis-la-Culture ${ }^{20}$. Po owych dwóch tragicznych eksplozjach w Paryżu nie dziwi skierowanie ze stolicy do władz poszczególnych dystryktów ostrych nakazów w zakresie ochrony depozytów narodowych przed groźbą pożarów czy wybuchów ${ }^{21}$. Pomimo powtarzających się zaleceń w prawie całym XIX wieku, nawet w czasach pokoju, płonące biblioteki nie należały do rzadkości. Wprawdzie odizolowano książnice od niebezpiecznych miejsc, ale prymitywne ogrzewanie i oświetlenie najpierw naftowe, nieco później gazowe - było równie zdradliwe i przyczyniało się do wywoływania licznych pożarów.

Wróćmy do trzeciego raportu ojca Grégoire'a, z 24 frimaire'a roku III (14 grudnia 1794 r.). Pominiemy utyskiwania autora na zaniedbania, cynizm i przebiegłość lokalnych władz, które nie raczą poświęcać zbyt wiele energii na dopilnowanie i uporządkowanie swoich depozytów, natomiast zbyt często chcą na nich zarobić lub wykorzystać je w inny sposób. Na uwagę zasługuje jednak odnotowany przez jezuitę fanatyzm - główny czynnik niszczycielski, zmiatającego ze swej drogi wszelkie dzieła $\mathrm{w}$ jakikolwiek sposób mogące być powiązane $\mathrm{z}$ epoką ancien régime'u. Tutaj metodą dominującą są celowo organizowane palenia książek oraz wyrywanie ich niepopularnych fragmentów, okładek, ilustracji, o czym już wspominano. Ponownie na jednym z czołowych miejsc sytuuje się polityczny, zataczający wręcz międzynarodowe kręgi, wandalizm. Tym razem jego aktów dopuszcza się wróg zewnętrzny - Anglia, która podburza wszystkie wrogie republikańskiej Francji kontrrewolucyjne ugrupowania do takiego działania, ażeby zdyskredytować ją w oczach Europy $^{22}$. Oczywiście, ówczesna I Republika miała trochę więcej wrogów na świecie niż ów odwieczny przeciwnik - brytyjski, który wypowiedział jej wojnę dopiero po ścięciu króla Ludwika XVI. Niemniej to właśnie ten sąsiad najbardziej przemawiał do wyobraźni Francuzów, od zawsze postrzegających Anglików negatywnie i podejrzewających ich o ciagłe spiskowanie. Nawet jeśli znajdowano pojedyncze wyjątki potwierdzające diagnozę międzynarodowego spisku przeciwko dobrom kultury, jak np. działalność brytyjskich tajnych agentów zmierzająca do niszczenia „wrogich” bibliotek przysyłanych do Francji przez znienawidzonego

${ }^{20}$ Zob. G.K. Barnett, dz. cyt., s. 42.

${ }^{21}$ Zob. jak wyżej.

${ }^{22}$ Zob. tamże, s. 41. 
Williama Pitta $^{23}$, przypuszczenia te miały bardziej charakter prewencyjny i były obliczone na oddziaływanie na wyobraźnię tych, którzy byli w staniezapobiec podobnym aktom, a więc pobudzić Konwent do działania. Już w lutym 1794 r. ojciec Grégoire donosił: „cudzoziemcy, nie mogąc pokonać Republiki poprzez siłę wojsk, wydzieraja jej dzieła sztuki, które ją wzbogacają"24, a w maju w kolejnym raporcie dodawał: „popełniaja zbrodnie, ażeby mieć satysfakcję właśnie nam je przypisywać, traktując nas jako barbarzyńców, którzy odmawiają azylu sztuce" ${ }^{25}$. Takie skryte knucie przeciwko kulturze to najwyższy poziom zhańbienia, pisał dalej Grégoire, które to próbują imputować obywatelom Francji wrodzy agenci. Chyba nie w aż tak ostrych barwach widziała obcą działalność wywiadowczą Konwencja, skoro na pierwszym miejscu postawiła ochronę bibliotek i depozytów przed ogniem (zabraniono trzymania wewnątrz nich bądź w okolicy jakiejkolwiek broni, amunicji czy materiałów łatwopalnych i nałożono na władze lokalne dodatkowe obowiązki mające służyć natychmiastowemu zabezpieczeniu zbiorów przed pożarami). Nic z kolei nie wspomniano o rzekomych tajnych agentach i szpiegach.

Wandalizm (neologizm ten został użyty po raz pierwszy w odniesieniu do dóbr kultury przez Josepha Lakanala w jego raporcie dla Konwencji w 1793 r. $^{26}$, a ojcu Grégoire'owi zawdzięcza jedynie rozpowszechnienie) mieścił $\mathrm{w}$ sobie o wiele więcej możliwości interpretacyjnych odnośnie charakteryzowanej grupy obiektów niż zwykła kradzież, destrukcja, zniszczenie. Analizujący powyższe zjawisko historycy, na czele z S. Bianchi ${ }^{27}$ i D. Hermantem ${ }^{28}$, nie wyczerpując rezerwuaru różnych „wandalizmów” ukazywanych przez H. Grégoire'a, wskazują na niesamowitą popularność i pojemność samego pojęcia, mówią o jego nadużywaniu, a co za tym idzie - o fałszowaniu faktycznego obrazu zniszczeń, jak i o budowaniu właśnie na podstawach tego nieprawdziwego opisu

${ }^{23}$ Zob. R. Hermon-Belot, dz. cyt., s. 305.

${ }^{24}$ „Les étrangers, ne pouvant vaincre la République par la force des armes, cherchent à la déshonorer en lui enlevant les monuments des arts dont elle est enrichie" - cyt. za : R. Hermon-Belot, dz. cyt., s. 305.

${ }^{25}$ „Commettre des crimes pour savoir le plaisir de nous les imputer en nous traitant de barbares qui refusaient un asile aux arts" - cyt. za: jak wyżej.

${ }^{26}$ Zob. tamże, s. 304.

${ }^{27}$ Historyk ów wyróżnia wandalizm codzienny i polityczny, antyfeudalny, jak i antyklerykalny; wymienia też wandalizm antykulturowy, prowadzący do palenia książek, rabowania bibliotek oraz wandalizm antynaukowy, w którym mieści się np. niszczenie ogrodów botanicznych, kolekcji roślin czy zabijanie zwierząt. Szerzej zob. S. Bianchi, dz. cyt., s. 392-395.

${ }^{28}$ D. Hermant dorzuca z kolei do typologii Bianchiego wandalizm obywatelski i patriotyczny, czyli np. niszczenie nieprawych, tj. niezgodnych z duchem epoki, pomników i obrazów w imię nowych cnót obywatelskich - zob. D. Hermant, dz. cyt., s. 711. 
potrzeby wspólnoty dziedzictwa narodowego, ujmowanej w kategoriach oporu czy przeciwstawienia się wszechobecnemu złu.

To przede wszystkim szeroko pojmowany i różnie wartościowany wandalizm, związany zarówno z faktyczną, jak i symboliczną przemocą wobec dóbr kultury, przyczynił się do narodzin w świadomości Francuzów, a następnie i całej Europy, podstawowej wartości jednoczącej naród, jaką jest jego historyczne dziedzictwo i konieczność ochrony tej spuścizny ${ }^{29}$. U podstaw stworzenia, jeszcze na przełomie XVIII i XIX wieku, tej typowo francuskiej koncepcji legła konieczność przystosowania znacjonalizowanych dóbr do potrzeb nowego społeczeństwa, ale też ich ochrony przed owym społeczeństwem. W cytowanej biografii ojca Grégoire'a jej autorka - R. Hermon-Belot - właśnie jemu przypisuje wprowadzenie pojęcia patrymonium narodowego (patrimoine national) do polityki i życia codziennego Francji. Ksiądz Grégoire konsekwentnie tłumaczył rewolucjonistom, że przejmowanie różnych dóbr kultury, na czele z bibliotekami, to usprawiedliwione przywrócenie ludowi jego własnego dziedzictwa narodowego. Wzmacniał swe słowa wymownymi argumentami, jak na przykład takim, że cała literatura i sztuka to nic innego tylko, ,praca i pot narodu" ${ }^{30}$. W takim ujęciu państwo jawi się jako gwarant własności narodowej. Najistotniejszym praktycznym objawem tego stanu rzeczy ma być, poza jej ochroną, wolny dostęp do tak pojmowanych dóbr. I nie chodziło tu tylko o książki i biblioteki publiczne. Ojciec Grégoire na własną rękę próbował np. otworzyć na potrzeby ludu część pałacu biskupiego w Blois, a swoich kolegów namawiał, ażeby poszli w jego ślady i wreszcie wprowadzili rewolucję do literatury, sztuki, zamków, kościołów, czyli przekazali je całemu narodowi. W mniemaniu jezuity pojęcie dziedzictwa narodowego nie ogranicza się tylko do prostego kolekcjonowania książek i rzeczy, posiadania nieruchomości, tworzenia muzeów, lecz winno się przede wszystkim wyrażać w działaniu o charakterze moralizatorskim i w powszechnym udostępnianiu zbiorów. Dla ogółu obywateli, którzy odpowiadają za wybuch rewolucji i są jej aktorami, wszelkie publiczne pomniki winny przypominać ich własne zasługi, odwagę, zwycięstwa i prawa, a tym samym przyczyniać się do podnoszenia poczucia godności i obywatelskiej dumy. Winny niejako przemawiać do ludzi językiem, „który będzie nośnikiem patriotyzmu i cnoty, którą obywatele na wskroś będą przeniknięci" ${ }^{31}$. Dalej,

${ }^{29}$ Zob. D. Varry, Une Histoire des destructions et de l'oubli, [w:] Le Patrimoine. Histoire, pratiques et perspectives, sous la direction de Jean-Paul Oddos, Paris 1997, s. 79.

${ }^{30}$ „le travaille et la sueur de Nation” - cyt. za: R. Hermon-Belot, dz. cyt., s. 329.

31 "qui sera le porteur du patriotisme et de la vertu dont les citoyens seront percé" cyt. za: tamże, s. 330 . 
wskazując jeszcze wymowniej na aspekt edukacyjny patrymonium narodowego, Grégoire podkreślał, że wszelkie pamiątki dziejowe mają przyciagać również, a może przede wszystkim, wzrok. Nie bez powodu na początku naszych rozważań podkreśliliśmy działalność zakonnika w zakresie oświaty, a także odebrane przez naszego bohatera jezuickie wykształcenie. $\mathrm{W}$ projektowanym przez niego modelu dziedzictwa narodowego pierwsze miejsce zajmowały wartości samokształceniowe, nieco w tyle natomiast pozostawała kwestia przekazu międzypokoleniowego i ciagłości historycznej. Niezbyt pomyślnie wyglądało też zagadnienie oddzielenia dziedzictwa narodowego od polityki, gdyż w rozumieniu ojca Grégoire'a patrymonium należało do narodu, ale Republika miała jeszcze większe prawa do tej spuścizny, a skoro tak, to państwo mogło na jej rzecz interweniować i udoskonalać ją w imię potrzeb ludu. W raporcie księdza na temat inskrypcji na budowlach publicznych odnajdujemy jawne przyzwolenie na dewastację wszystkich tych, które zawierają symbolikę rojalistyczną czy też feudalną ${ }^{32}$, i na tym polegał właśnie ów wandalizm patriotyczny. $Z$ drugiej strony, podkreślając na każdym kroku, że Francja jest ziemią wolności, a Paryż - stolicą humanizmu, ojciec Grégoire triumfalnie donosił w tymże samym 1794 r. Konwentowi, że Crayer, Vandyk i Rubens są w drodze do Paryża i, że szkoła flamandzka wyniesiona tym razem dla mas ozdobi nasze muzea $^{33}$. W innym miejscu chlubił się z pozyskania dla Biblioteki Narodowej brakującego egzemplarza dzieł Tytusa Liwiusza ${ }^{34}$. Jezuita - mimo odczuwania wagi odzyskiwanego dziedzictwa narodowego - nie potrafi jeszcze całościowo zdefiniować jego społecznej roli. I znów, podobnie jak w przypadku wandalizmu, mamy do czynienia z - sygnowaną polityczna poprawnością epoki - wieloznacznością pojęcia dobra narodowego i patrymonium, w tym tego literackiego.

Francja, która od dawna szczyci się najlepszą promocją swego narodowego dziedzictwa kulturowego, najskuteczniej chronionego przez różnego rodzaju ustawy i przepisy legislacyjne, jest drugim po Włoszech najbardziej splądrowanym krajem w dziejach Europy i świata. W 1996 r. Ministerstwo Spraw Wewnętrznych Francji oszacowało wszelkie rabunki dzieł sztuki na

${ }^{32}$ Niszczenie znienawidzonych śladów ancien règime'u zostało zresztą zadekretowane urzędowo - 18 vendéimaire'a II r. (9 października 1793 r.) Konwencja uchwaliła stosowne prawo o destrukcji wszelkich widocznych symboli władzy królewskiej czy feudalnej. I chociaż ponad dwa tygodnie później, 24 października 1793 roku, wyszedł zakaz wyrywania kart, opraw, czyli niszczenia książek zaopatrzonych np. w rodowe exlibrisy, nie powstrzymało to zapoczątkowanej już dewastacji. Więcej na ten temat zob.

J. Dumaine, dz. cyt., s. 272.

${ }^{33}$ Zob. R. Hermon-Belot, dz. cyt., s.343.

${ }^{34}$ Zob. tamże, s. 344. 
17 tys. obiektów ${ }^{35}$. Wprawdzie nie ustalono (nie znaleziono) podobnych statystyk odnośnie dziedzictwa dokumentalnego czy szerzej - piśmienniczego, ale wydaje się, że z powodu grabieży rewolucji zajmowałaby i pod tym względem jedno z pierwszych miejsc. Nie zapominajmy, że etykieta „dziedzictwo” we współczesnych bibliotekach dotyczy tylko marginalnej części zbiorów i że nadal biblioteki, nawet te narodowe, mają kłopot z wyróżnieniem owego właściwego patrymonium, o czym najlepiej świadczy fakt ich nieobecności podczas licznych imprez związanych z obchodami roku 1980, poświęconego we Francji dziedzictwu narodowemu. Instytucje te, przystapiwszy z opóźnieniem do dyskusji na temat, co należy uznać za piśmiennicze dziedzictwo narodowe, nie zdołały wypracować jasnej metodologii tzw. ,procesu patrymonializacji” (,le processus de patrimonialisation" $)^{36}$. Jeśli za podstawowe kryterium procesu kształtowania się dziedzictwa chcemy uznać historię i upływający czas, musimy pamiętać, że nie jest to czynnik jedyny i wyczerpujący. Wydaje się, że tak jak wandalizm minionego okresu przyspieszył ukonstytuowanie się nowożytnego pojęcia dziedzictwa narodowego końca XVIII wieku, tak współcześnie informatyzacja książki i kultury może w pewnej perspektywie powodować podobne skutki - generować nowy zakres terminu, przynajmniej jeśli chodzi o piśmiennicze dziedzictwo narodowe, europejskie lub światowe. Czy rzeczywiście będzie to możliwe - czas pokaże.

\section{Streszczenie}

\section{W obronie francuskiego dziedzictwa kulturowego. Działalność Henri Grégoire na rzecz ochrony książki i sztuki w okresie Wielkiej Rewolucji Francuskiej}

Artykuł jest poświęcony ochronie francuskiego dziedzictwa piśmienniczego w okresie Wielkiej Rewolucji 1789 i tuż po jej zakończeniu. Zanim kolejne władze rozpoczęły planowe zapobieganie dewastacjom bibliotek i niszczenia archiwaliów z okresu znienawidzonego ancien régime, należało zarówno im, jak i całemu społeczeństwu uświadomić znaczenie dokumentów i księgozbiorów historycznych w budowie nowego państwa. Do tego miało służyć wprowadzenie pojęcia patrymonium narodowego. Jednak przekonanie, szczególnie Stanu Trzeciego, że to co, kiedyś było prywatne, kościelne, szlacheckie, teraz jest dobrem całego narodu i podlega ochronie, wcale nie było proste. Wyjątko-

\footnotetext{
${ }^{35}$ Zob. D. Varry, dz. cyt., s. 68.

${ }^{36} \mathrm{O}$ różnych drogach owego procesu patrymonializacji zob. tamże, s. 81-89.
} 
wą rolę w owym procesie uświadamiania, ale też tworzenia zrębów owego piśmienniczego dziedzictwa narodowego Francji odegrał jezuita - Henri Grégoire. W swych kolejnych raportach przesyłanych do Konwentu ukazywał wandalizm wobec „słowa pisanego”, obnażał głupotę oprawców, przedstawiał niewyobrażalne metody i skalę barbarzyństwa wobec znacjonalizowanych bibliotek. Ów tragiczny obraz stanu francuskiej kultury piśmienniczej kreślił po to, ażeby zmusić władze do podjęcia działań w celu zapobieżenia zniszczeniom.

Dzięki jego niestrudzonej pracy udało się ocalić od zniszczeń dziesiątki tysięcy cennych woluminów i archiwów, ale co ważniejsze na stałe wprowadził do francuskiej myśli historycznej takie pojęcia jak rewolucyjny wandalizm, dziedzictwo narodowe i konieczność jego ochrony.

\section{Summary}

\section{In Defence of the French Cultural Heritage: The Activities of Henri Grégoire as Protector of Books and Art During the French Revolution}

The article deals with the protection of the French literary heritage during the Revolution of 1789, and shortly afterwards. Revolutionary attitudes resulted among others with the devastation of libraries and archives, which the people mentally associated by with the detested ancien régime. Before the new authorities could introduce institutional measures to stop these ruinous tendencies, it was indispensible that the members of the new administration themselves, and the society as a whole, acknowledged the fundamental role of document and book collections for the of the new state. To this end the notion of "national heritage" was introduced. But, convincing the people, and the Third Estate in particular, that what formerly belonged to private individuals, the Church, or aristocracy, is now the property of the nation, turned out to be difficult. The Jesuit Henri Gregoire played an important part not only in the process of educating the people in this sphere, but also in the constructing of the idea of national heritage itself. In a series of reports addressed to the Convent, he revealed the foolishness and vandalism of the individuals who wreaked chaos in the libraries, and pointed to the scale of the barbarism, with which the "written word" was treated. He emphasized the tragic state of the French literary culture in order to instigate the authorities to undertake measures, which would put an end to further destruction.

Thanks to the unrelenting efforts of Henri Gregoire tens of thousands of valuable books and documents were saved from annihilation. But, what perhaps proved even more important, he introduced into the French historical thought such concepts as revolutionary vandalism and the national heritage, and propagated the necessity of protecting the latter. 